\title{
Optimization of an Analytical Protocol for the Extraction, Fractionation and Determination of Aromatic and Aliphatic Hydrocarbons in Sediments
}

\author{
Vânia R. Ferreira, ${ }^{a}$ Cindy D. Gouveia,${ }^{a}$ Cesar A. da Silva, ${ }^{a}$ \\ Andreia N. Fernandes ${ }^{b}$ and Marco T. Grassi ${ }^{*}, a$ \\ ${ }^{a}$ Departamento de Química, Universidade Federal do Paraná, \\ 81531-990 Curitiba-PR, Brazil \\ ${ }^{b}$ Instituto de Química, Universidade Federal do Rio Grande do Sul, \\ 91501-970 Porto Alegre-RS, Brazil
}

\begin{abstract}
Neste trabalho foram aperfeiçoadas as etapas para determinação de hidrocarbonetos alifáticos e aromáticos em sedimentos. Durante as etapas de extração e concentração foram avaliados fatores determinantes como tempo, solvente extrator e sistema de resfriamento. Quanto ao cleanup, foram estudados diferentes volumes e misturas de solventes de eluição. Os resultados obtidos foram considerados aceitáveis (70-120\%). A linearidade, limites de detecção e quantificação foram estudados construindo-se curvas analíticas $(R>0,99)$ com valores que demonstraram grande sensibilidade do método. A precisão e exatidão foram avaliadas com ensaios envolvendo material de referência certificado e adição e recuperação de analitos em sulfato de sódio. Nos testes de adição e recuperação os desvios ficaram abaixo de $20 \%$, com recuperação dos alifáticos e aromáticos de $59-105 \%$ e $55-113 \%$, respectivamente. Para os sedimentos de referência, os desvios obtidos foram inferiores aos valores certificados, com recuperações satisfatórias. O presente trabalho proporcionou a melhoria de um método já consolidado, possibilitando obter resultados com elevada confiabilidade analítica.
\end{abstract}

The main steps involved in the determination of aliphatic and aromatic hydrocarbons in sediments were evaluated in this work. In the extraction, factors such as the cooling system, time and solvent were evaluated. During the extraction and concentration, steps aspects such as time, extraction solvent and cooling system were evaluated. In the cleanup different solvents and elution mixtures were studied. The results were considered satisfactory (70-120\%). Linearity and limits of detection and quantification were studied by means of calibration curves $(R>0.90)$ and the results demonstrated high sensitivity of the method. Precision and accuracy were studied by recovery tests using a certified reference material and sodium sulfate. In recovery tests, the standard deviations were below $20 \%$, with percent recoveries for aliphatic and aromatics ranging from 59 to $105 \%$ and 55 to $113 \%$, respectively. For the reference sediment, the standard deviations were lower than the certified values, with satisfactory recovery values. The present work provided a way of improving an already established method with high analytical reliability.

Keywords: hydrocarbons, Soxhlet extraction, sediment, gas chromatography, validation

\section{Introduction}

Aliphatic and polycyclic aromatic hydrocarbons (PAH) have an important role in environmental studies, particularly those related to the investigation of sediment contamination by oil and its derivatives. Due to their low solubility in water, hydrocarbons are mainly deposited in

*e-mail: mtgrassi@ufpr.br sediments, ${ }^{1}$ and prior to their determination an extraction step to remove them from the matrix is required.

The determination of hydrocarbons in sediments can be divided in two steps. The first one is related to sample preparation for obtaining an extract containing only the target compounds and comprises the following stages: (i) sediment sampling, storage and preparation; (ii) extraction; (iii) removal of interfering compounds and fractionation (cleanup); (iv) analytes concentration. The second step involves the chromatographic separation of 
individual compounds. In each of the steps, care must be exercised to not compromise the expected results.

Several methods for hydrocarbons extraction from sediment samples have been described, and the most frequently used are Soxhlet, ${ }^{2-5}$ ultrasonic extraction ${ }^{6,7}$ and mechanical shaking. ${ }^{8-10}$ Other approaches have also been applied, such as accelerated solvent extraction (ASE), ${ }^{11,12}$ supercritical fluid extraction (SFE) ${ }^{13,14}$ and microwaveassisted extraction (MAE). ${ }^{15-17}$ Each technique has its advantages and disadvantages and the suitability depends on several factors, such as capital and operational costs, facility use, and availability of materials and equipment in the laboratory. Sometimes, an important factor to be considered is the use of a validated and consolidated method. This occurs particularly when the analytical results are demanded in cases of environmental risk assessment, which always involve spending of financial resources, allocation of human resources and legal actions. ${ }^{18}$ However, validated and consolidated methods, in some cases, have deficiencies that must be improved, being the Soxhlet use a case.

Different studies reporting comparison of other techniques versus Soxhlet extraction showed that the latter one was more efficient. ${ }^{19-21}$ Although capable of yielding good results and the recommendation by the US Environmental Protection Agency ${ }^{22}$ as the standard method for hydrocarbon determination in environmental matrices, this method presents a number of disadvantages such as high solvent consumption (60 to $200 \mathrm{~mL}$ ) and long extraction times (6-48 h). Despite these disadvantages, Soxhlet extraction remains the most suggested guideline method when hydrocarbons fingerprinting data are used in environmental litigation involving oil and its derivatives spills and accidents, for example.

In addition to the extraction step, in some other stages, such as concentration and cleanup, some analytes losses may occur, especially by volatilization. Furthermore, the analytes can be retained in the adsorbent phase of the liquid-solid chromatographic column if an elution solvent with appropriate characteristics was not chosen. Therefore, these steps are considered critical since their effects will be added to the extraction step in order to obtain accurate results.

Although considered as a reference method, the extraction parameters of hydrocarbons by Soxhlet can differ dramatically, as summarized in Table 1. These differences show that there is a lack of consensus in the analytical procedures of organic pollutants extraction from environmental matrices, even in cases where protocols are internationally validated and are also recognized as reference. ${ }^{18}$

Considering these aspects, the main goal of this study was to evaluate the critical steps implicated in the determination of aliphatic and aromatic hydrocarbons in sediments by Soxhlet, aiming the improvement of an already established method.

\section{Experimental}

\section{Materials and reagents}

All reagents and organic solvents used in this work for the determination of trace concentrations of the target compounds were of high purity (HPLC grade). Anhydrous sodium sulfate, copper powder, Extran ${ }^{\circledR}$ detergent and silica gel (70-230 mesh) were supplied by Merck (Darmstadt, Germany); acetone, dichloromethane (DCM) and n-hexane were supplied by Mallinckrodt (USA). Before use, anhydrous sodium sulfate was purified by heating at $400{ }^{\circ} \mathrm{C}$ for $4 \mathrm{~h}$; copper powder was activated by treating with hydrochloric acid $\left(6 \mathrm{~mol} \mathrm{~L}^{-1}\right)$, rinsed with methanol, methanol:DCM and dichloromethane and was dried under a nitrogen stream; silica gel and alumina were activated at $165^{\circ} \mathrm{C}$ for $16 \mathrm{~h}$, and deactivated with Milli-Q type water $(2 \% \mathrm{~m} / \mathrm{m})$. Synthetic air, helium, nitrogen and hydrogen gases (purity 99.9999\%) were supplied by White Martins (Curitiba, Brazil).

A mix of 16 polycyclic aromatic hydrocarbons (PAH) priority pollutants according to the US EPA containing

Table 1. Different working conditions of extraction, concentration and cleanup procedure for hydrocarbons determination by Soxhlet method

\begin{tabular}{lccc}
\hline \multirow{2}{*}{ Reference } & & Working conditions & \\
\cline { 2 - 4 } 3 & Extraction time (solvent) $/ \mathrm{h}$ & Concentration procedure & Cleanup elution solvent \\
21 & 24 (hexane/DCM) & rota-evaporator $+\mathrm{N}_{2}$ & aliphatic: hexane \\
20 & 7 (hexane/DCM) & Kuderna-Danish & not described \\
23 & 16 (hexane/acetone) & rota-evaporator & solid phase extraction (SPE) \\
& & $\mathrm{N}_{2}$ & aliphatic: hexane \\
\hline
\end{tabular}

aPAH: polycyclic aromatic hydrocarbons; ${ }^{\mathrm{b}} \mathrm{DCM}$ : dichloromethane. 
naphthalene (Nap), acenaphthylene (Acy), acenaphthene (Ace), fluorene (Flu), phenanthrene (Phe), anthracene (Ant), fluoranthene (Fluo), pyrene (Pyr), benzo[a]anthracene (BaA), chrysene (Chry), benzo[k]fluoranthene (BkF), benzo[b]fluoranthene $(\mathrm{BbF})$, benzo[a]pyrene $(\mathrm{BaP})$, indene[1,2,3-cd]pyrene (IP), dibenzo[a,h]anthracene (DahA) and benzo[g,h,i]perylene (Bghi) (Accustandard Inc, USA) was used as analytical standard. A mix of deuterated PAH containing naphthalene- $\mathrm{d}_{8}$, anthracene- $\mathrm{d}_{10}$, pyrene- $\mathrm{d}_{10}$, crysene- $\mathrm{d}_{12}$ and perylene- $\mathrm{d}_{12}$ (Accustandard Inc, USA) was used as internal standard and $p$-terphenyl- $\mathrm{d}_{14}$ as surrogate. For the aliphatic hydrocarbons (AH) determination a mix of n-alkanes $\left(\mathrm{C}_{8}-\mathrm{C}_{40}\right)$ was used as calibration standards; deuterated hexadecane $\left(\mathrm{n}-\mathrm{C}_{16 \mathrm{~d}}\right)$ was used as internal standard and deuterated eicosane $\left(n-C_{20 d}\right)$, tetracosane $\left(n-C_{24 d}\right)$ and triacontane $\left(\mathrm{n}-\mathrm{C}_{30 \mathrm{~d}}\right)$ were used as surrogates. Sediment reference material was supplied by Laboratory for Marine and Environmental Studies (PUC-Rio, Brazil) and a certified reference material NWRI EC-3 (Lake Ontario sediment) was supplied by National Water Research Institute, Environment Canada (Burlington, Canada).

\section{Concentration, extraction and cleanup step evaluation}

To evaluate analyte losses during the concentration, extraction and cleanup steps, recovery tests were performed using solutions of known concentration of alkanes, PAH and surrogates. In the concentration step, the temperature of the cooling system of the rota-evaporator was evaluated. It was also studied the influence of nitrogen stream used and the number of rinses to recover the analytes. In the first test, the total volume of solvent was evaporated and the analytes were reconstituted in $1 \mathrm{~mL}$ of hexane:DCM. In another test, the first assessment consisted of reducing the volume of the solvent to about $2 \mathrm{~mL}$ on the rota-evaporator (with or without ice bath) and concentration to $1 \mathrm{~mL}$ under a flow of nitrogen using a pressure of $2 \mathrm{kgf} \mathrm{cm}^{-2}$ without rinsing the flask. In this step, the temperature of the rota-evaporator bath used was of $50 \pm 1{ }^{\circ} \mathrm{C}$. A second test using a pressure of $0.5 \mathrm{kgf} \mathrm{cm}^{-2}$ with subsequent washing of the flask three times with the appropriate solvent was also performed. In a third test, the solvent volume was reduced to approximately $1 \mathrm{~mL}$ on the rota-evaporator.

In the extraction process, the influence of temperature on the cooling system of the Soxhlet extractor was evaluated. Different extraction times (4, 6 and 8 h) and different solvents were also studied.

In the cleanup step, a solution with known concentrations of AH and PAH was eluted through a chromatographic glass column $(11 \mathrm{~mm}$ i.d. $\times 300 \mathrm{~mm})$ packed with $0.120 \mathrm{~g}$ of activated copper at the bottom, $8 \mathrm{~g}$ of silica, $1.0 \mathrm{~g}$ of alumina and $0.600 \mathrm{~g}$ of anhydrous sodium sulfate. Different elution volumes were studied for $\mathrm{AH}\left(\mathrm{F}_{1}\right)$ and different solvent mixtures for the elution of the PAH fraction $\left(\mathrm{F}_{2}\right)$ were also tested. Several experiments to determine the total petroleum hydrocarbons (TPH) (mixing $\mathrm{F}_{1}$ and $\mathrm{F}_{2}$ ), as well as the fractionation of aliphatic and aromatic hydrocarbons in distinct fractions, were conducted.

\section{Recovery tests}

In order to evaluate the efficiency of the extraction, recovery studies adding known concentrations of aliphatic hydrocarbons, PAH and surrogates in anhydrous sodium sulfate were performed. Standard solution of $150 \mathrm{ng} \mathrm{mL}^{-1}$ of PAH and $10 \mu \mathrm{g} \mathrm{mL}^{-1}$ of AH were added to an extraction cellulose thimble, previously decontaminated, containing $4 \mathrm{~g}$ of anhydrous sodium sulfate. The compounds were extracted with $200 \mathrm{~mL}$ of $\mathrm{DCM}$, of which $50 \mathrm{~mL}$ were directly added into the extractor. The extraction was performed for a period of $4 \mathrm{~h}$, keeping six extraction cycles per $\mathrm{h}$ to achieve better recoveries. The extract was reduced up to $2 \mathrm{~mL}$ in a rota-evaporator for subsequent fractionation, concentration and chromatographic analysis.

Aliphatic and aromatic hydrocarbons extraction from a reference material and certified reference material

A blend of $4 \mathrm{~g}$ of the reference sediment and $2 \mathrm{~g}$ of activated copper powder was placed in a previously decontaminated extraction thimble and surrogates spike solution were added (deuterated PAH $150 \mathrm{ng} \mathrm{mL}^{-1}$ and AH $10 \mu \mathrm{g} \mathrm{m}^{-1}$ standards). The NWRI EC-3 reference material was analyzed in order to assess the accuracy of the proposed method including all steps from extraction and concentration, through cleanup to GC-MS (gas chromatographic with mass spectrometric detection) analysis. The extraction procedure was performed as earlier described.

\section{Quality assurance and quality control (QA/QC)}

QA/QC tests were carried out in order to monitor and control potential losses or sources of contamination during all steps. Blank extractions using sodium sulfate previously heated at $450{ }^{\circ} \mathrm{C}$ were performed. Moreover, there was also the possibility of contamination during the sample concentration. For this study, $180 \mathrm{~mL}$ of hexane was added to a flask, the volume was reduced to about $1 \mathrm{~mL}$ in a rota-evaporator and an aliquot of $1 \mu \mathrm{L}$ was injected in the GC-MS and GC-FID (flame ionization detector). 
Concomitantly, other test was carried out to monitor possible contamination from the $\mathrm{N}_{2}$ used to concentrate samples. Approximately $2 \mathrm{~mL}$ of the solvent was reduced to $1 \mathrm{~mL}$ under a $\mathrm{N}_{2}$ stream and then injected into the gas chromatograph. Aliphatic and aromatic hydrocarbons were not detected in the blank analysis, so no blank correction was necessary and no source of contamination was detected during this procedure.

AH identification was based on retention times of corresponding standards, which were injected and analyzed under the same conditions as samples. Analytical curves ranged from 0.5 to $50 \mu \mathrm{g} \mathrm{mL} \mathrm{m}^{-1}$ using $\mathrm{n}-\mathrm{C}_{16 \mathrm{~d}}$ as internal standard $\left(10 \mu \mathrm{g} \mathrm{mL}^{-1}\right)$ and from $1-25 \mu \mathrm{g} \mathrm{mL} \mathrm{m}^{-1}$ for the surrogate hydrocarbons $\left(\mathrm{n}-\mathrm{C}_{20 \mathrm{~d}}, \mathrm{C}_{24 \mathrm{~d}}\right.$ and $\mathrm{C}_{30 \mathrm{~d}}$ ). The identification of PAH was performed by injecting a standard solution containing a mixture of $16 \mathrm{PAH}$ and by comparison with the NIST (National Institute of Standards and Technology) mass spectra library. The analytical curve was obtained in the concentration ranging from 9.6 to $1000 \mathrm{ng} \mathrm{mL}^{-1}$ using deuterated PAH (naphthalene- $\mathrm{d}_{8}$, acenaphthene- $\mathrm{d}_{10}$, phenanthrene- $\mathrm{d}_{10}$, chrysene- $\mathrm{d}_{10}$, perylene- $\mathrm{d}_{12}$ ) as internal standards at $96 \mathrm{ng}$ $\mathrm{mL}^{-1}$ individual concentration. An analytical curve for the surrogate standard $p$-terphenyl- $\mathrm{d}_{14}$ in the concentration range 9.6-200 $\mathrm{ng} \mathrm{mL}^{-1}$ was also built.

\section{Instrumentation and apparatus}

The AH determination was performed in a Focus GC gas chromatograph (Thermo Electron Corporation), equipped with flame ionization detector, split/splitless injector and with nitrogen at a rate of $3 \mathrm{~mL} \mathrm{~min}{ }^{-1}$ as carrier gas. Samples were separated in an OV-5 capillary column with $30 \mathrm{~m}$ length $\times 0.32 \mathrm{~mm}$ i.d. $\times 0.25 \mu \mathrm{m}$ film thickness. The oven temperature was programmed as follow: $60^{\circ} \mathrm{C}$ for $1.5 \mathrm{~min}$, increasing $6{ }^{\circ} \mathrm{C} \mathrm{min}^{-1}$ to $310{ }^{\circ} \mathrm{C}$ and held for $30 \mathrm{~min}$. Injector and detector temperatures were 280 and $300{ }^{\circ} \mathrm{C}$, respectively. The injection volume was $1 \mu \mathrm{L}$ in splitless mode (1 min). GC-MS analyses were performed using Focus GC instrument (Thermo Electron Corporation) equipped with a Polaris Q Mass spectrometer (Thermo Electron Corporation) and a split/splitless injector. The capillary column used was an OV-5ms capillary column with $30 \mathrm{~m}$ length $\times 0.25 \mathrm{~mm}$ i.d. $\times 0.25 \mu \mathrm{m}$ film thickness with helium as carrier gas $\left(1 \mathrm{~mL} \mathrm{~min}^{-1}\right)$. The oven temperature was programmed as follow: $50{ }^{\circ} \mathrm{C}$ held for $1.5 \mathrm{~min}$, then increased at $1.5^{\circ} \mathrm{C} \mathrm{min}{ }^{-1}$ to $230^{\circ} \mathrm{C}, 2^{\circ} \mathrm{C} \mathrm{min}^{-1}$ to $250{ }^{\circ} \mathrm{C}, 5^{\circ} \mathrm{C} \mathrm{min}{ }^{-1}$ to $300^{\circ} \mathrm{C}$ and held for $8 \mathrm{~min}$. Injector, transfer line and ion source temperature were 250,280 and $300{ }^{\circ} \mathrm{C}$, respectively. The injection volume was $1 \mu \mathrm{L}$ (splitless mode - $1 \mathrm{~min}$ ). The data were acquired when the instruments were operating in single-ion monitoring mode (SIM mode), grouping the ions in three segments, as follows: scan 1 (5 - $29 \mathrm{~min}): \mathrm{m} / \mathrm{z}, 128,136,152,154,162$, 164, 166, 178; scan 2 (30 - $47 \mathrm{~min}): \mathrm{m} / \mathrm{z}, 178,202,228$, 244 ; scan 3 (47 min, until the end of the run): $m / z$ 228, 236 240, 252, 260, 264, 276, 277, 278, 279.

\section{Results and Discussion}

Performance of the concentration, extraction and cleanup steps

\section{Concentration step}

The achievement of good working conditions for the development of the analytical process is of utmost importance and some steps are performed once or more. As a consequence, they are imperiled to errors and/or losses of analytes. This is the case of the pre-concentration of the analytes which is performed after the extraction and again after the cleanup steps. Thus, different tests were carried out in order to obtain the ideal experimental conditions in the concentration step. First, the use of an ice bath on the rota-evaporator condenser was evaluated. The recovery percentage for PAH ranged from 19 to $41 \%$ without the use of the ice bath and from 27 to $51 \%$ when the ice bath was employed. In addition, aspects such as the precision of the method were also enhanced when the ice bath was used, with the relative standard deviation ranging from 1.0 to $20 \%$. Despite the improvement in the process due to the use of the ice baths our results were still lower than the accepted range, which is recommended to be from 70 to $120 \% .^{24}$ The recovery tests for AH were performed using the system with the ice bath and the results ranged from 70 to $97 \%$.

Additional tests were performed in order to evaluate factors such as the partial or total evaporation of the solvent. The recovery results and relative standard deviation (RSD) obtained for AH and PAH are shown in Tables 2 and 3, respectively.

With the total drying of the solvent, the recovery percentage for $\mathrm{PAH}$ and $\mathrm{AH}$ compounds varied in the range of 2.0 to $82 \%$ and 16 to $108 \%$, respectively. Again, a great loss of the compounds, particularly for PAH with higher vapor pressure such as naphthalene, acenaphthene and for the shorter chain $\mathrm{AH}\left(\mathrm{C}_{12}-\mathrm{C}_{14}\right)$, was observed. By the other hand, when the solvent volume was reduced up to $1 \mathrm{~mL}$ only in the rota-evaporator, the obtained recovery values varied from 50 to $97 \%$ for PAH and from 49 to $99 \%$ for $\mathrm{AH}$. However, this approach significantly reduced the analytical throughput and increased the possibility of errors especially due to the difficulties in reaching the volume 
Table 2. Recoveries and RSD ( $=3$ ) obtained from PAH in the evaluation of concentration step

\begin{tabular}{|c|c|c|c|c|c|c|c|c|}
\hline \multirow{3}{*}{ PAH } & \multicolumn{8}{|c|}{ Working condition } \\
\hline & \multicolumn{2}{|c|}{$\begin{array}{c}\text { Drying + recovery } \\
\text { with solvent }\end{array}$} & \multicolumn{2}{|c|}{$\begin{array}{c}\text { Concentration only on } \\
\text { rota-evaporator }\end{array}$} & \multicolumn{2}{|c|}{$\begin{array}{c}\text { Dry by stream } \\
\left(\mathrm{N}_{2} \text { pressure / }\left(2 \mathrm{kgf} \mathrm{cm} \mathrm{cm}^{-2}\right)\right)\end{array}$} & \multicolumn{2}{|c|}{ 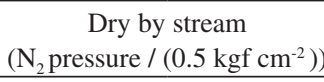 } \\
\hline & $\operatorname{Rec}^{\mathrm{a}} / \%$ & $\mathrm{RSD}^{\mathrm{b}} / \%$ & $\operatorname{Rec}^{\mathrm{a}} / \%$ & $\mathrm{RSD}^{\mathrm{b}} / \%$ & $\operatorname{Rec}^{\mathrm{a}} / \%$ & $\mathrm{RSD}^{\mathrm{b}} / \%$ & $\operatorname{Rec}^{\mathrm{a}} / \%$ & $\mathrm{RSD}^{\mathrm{b}} / \%$ \\
\hline Nap & 2.0 & 5.0 & 82 & 8.0 & 45 & 8.0 & 86 & 3.0 \\
\hline Acy & 2.0 & 1.0 & 92 & 6.0 & 40 & 10 & 93 & 1.0 \\
\hline Ace & 1.0 & 6.0 & 98 & 7.0 & 43 & 7.0 & 85 & 0.0 \\
\hline Flu & 3.0 & 5.0 & 86 & 10 & 46 & 6.0 & 90 & 4.0 \\
\hline Phe & 22 & 4.0 & 95 & 9.0 & 54 & 9.0 & 88 & 8.0 \\
\hline Ant & 22 & 4.0 & 96 & 9.0 & 61 & 9.0 & 96 & 8.0 \\
\hline Fluo & 39 & 3.0 & 88 & 8.0 & 61 & 9.0 & 91 & 3.0 \\
\hline Pyr & 47 & 3.0 & 89 & 6.0 & 50 & 5.0 & 99 & 7.0 \\
\hline $\mathrm{BaA}$ & 49 & 3.0 & 70 & 5.0 & 67 & 3.0 & 91 & 11 \\
\hline Chry & 38 & 3.0 & 82 & 5.0 & 54 & 2.0 & 93 & 12 \\
\hline $\mathrm{Bb} / \mathrm{kF}$ & 40 & 7.0 & 84 & 9.0 & 54 & 7.0 & 92 & 15 \\
\hline $\mathrm{BaP}$ & 61 & 5.0 & 57 & 2.0 & 68 & 3.0 & 88 & 15 \\
\hline IP & 54 & 3.0 & 89 & 1.0 & 67 & 5.0 & 78 & 18 \\
\hline DahA & 57 & 2.0 & 50 & 5.0 & 65 & 5.0 & 101 & 11 \\
\hline$\underline{\text { BghiP }}$ & 82 & 5.0 & 88 & 9.0 & 52 & 6.0 & 92 & 7.0 \\
\hline
\end{tabular}

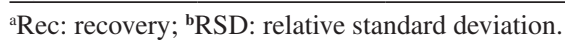

Table 3. Recoveries and RSD $(n=3)$ obtained from aliphatic hydrocarbons in the evaluation of concentration step

\begin{tabular}{|c|c|c|c|c|c|c|c|c|}
\hline \multirow{3}{*}{$\mathrm{AH}$} & \multicolumn{8}{|c|}{ Working condition } \\
\hline & \multicolumn{2}{|c|}{$\begin{array}{c}\text { Drying + recovery } \\
\text { with solvent }\end{array}$} & \multicolumn{2}{|c|}{$\begin{array}{c}\text { Concentration only on } \\
\text { rota-evaporator }\end{array}$} & \multicolumn{2}{|c|}{$\begin{array}{c}\text { Dry by stream } \\
\left(\mathrm{N}_{2} \text { pressure / }\left(2 \mathrm{kgf} \mathrm{cm} \mathrm{cm}^{-2}\right)\right)\end{array}$} & \multicolumn{2}{|c|}{$\begin{array}{c}\text { Dry by stream } \\
\left(\mathrm{N}_{2} \text { pressure } /\left(0.5 \mathrm{kgf} \mathrm{cm}^{-2}\right)\right)\end{array}$} \\
\hline & $\operatorname{Rec}^{\mathrm{a}} / \%$ & $\mathrm{RSD}^{\mathrm{b}} / \%$ & $\operatorname{Rec}^{\mathrm{a}} / \%$ & $\mathrm{RSD}^{\mathrm{b}} / \%$ & $\operatorname{Rec}^{\mathrm{a}} / \%$ & $\mathrm{RSD}^{\mathrm{b}} / \%$ & $\operatorname{Rec}^{\mathrm{a}} / \%$ & $\mathrm{RSD}^{\mathrm{b}} / \%$ \\
\hline $\mathrm{C}_{12}$ & 57 & 11 & 24 & 38 & 61 & 0.0 & 88 & 5.0 \\
\hline $\mathrm{C}_{13}$ & 61 & 10 & 30 & 23 & 61 & 1.0 & 93 & 5.0 \\
\hline $\mathrm{C}_{14}$ & 66 & 8.0 & 37 & 11 & 63 & 1.0 & 91 & 5.0 \\
\hline $\mathrm{C}_{15}$ & 70 & 6.0 & 46 & 4.0 & 65 & 1.0 & 89 & 6.0 \\
\hline $\mathrm{C}_{16}$ & 74 & 6.0 & 57 & 1.0 & 68 & 2.0 & 92 & 8.0 \\
\hline $\mathrm{C}_{17}$ & 80 & 5.0 & 69 & 6.0 & 60 & 19 & 93 & 7.0 \\
\hline Pristane & 80 & 4.0 & 70 & 5.0 & 60 & 19 & 89 & 2.0 \\
\hline $\mathrm{C}_{18}$ & 82 & 6.0 & 76 & 4.0 & 68 & 5.0 & 92 & 6.0 \\
\hline Phytane & 81 & 6.0 & 76 & 4.0 & 66 & 9.0 & 86 & 4.0 \\
\hline $\mathrm{C}_{19}$ & 83 & 7.0 & 76 & 3.0 & 72 & 0.0 & 90 & 5.0 \\
\hline $\mathrm{C}_{20}$ & 84 & 7.0 & 81 & 3.0 & 72 & 1.0 & 92 & 5.0 \\
\hline $\mathrm{C}_{21}$ & 86 & 8.0 & 84 & 4.0 & 73 & 2.0 & 92 & 5.0 \\
\hline $\mathrm{C}_{22}$ & 86 & 9.0 & 87 & 3.0 & 74 & 1.0 & 94 & 6.0 \\
\hline $\mathrm{C}_{23}$ & 82 & 15 & 89 & 4.0 & 77 & 5.0 & 91 & 6.0 \\
\hline $\mathrm{C}_{24}$ & 88 & 12 & 91 & 5.0 & 83 & 14 & 90 & 6.0 \\
\hline $\mathrm{C}_{25}$ & 90 & 13 & 94 & 7.0 & 91 & 21 & 88 & 6.0 \\
\hline $\mathrm{C}_{26}$ & 91 & 15 & 96 & 8.0 & 92 & 22 & 89 & 6.0 \\
\hline $\mathrm{C}_{27}$ & 92 & 17 & 98 & 9.0 & 93 & 21 & 85 & 6.0 \\
\hline $\mathrm{C}_{28}$ & 93 & 17 & 98 & 9.0 & 90 & 16 & 89 & 6.0 \\
\hline $\mathrm{C}_{29}$ & 92 & 16 & 100 & 9.0 & 85 & 8.0 & 83 & 6.0 \\
\hline $\mathrm{C}_{30}$ & 93 & 17 & 100 & 7.0 & 84 & 9.0 & 82 & 7.0 \\
\hline $\mathrm{C}_{31}$ & 93 & 17 & 102 & 5.0 & 81 & 4.0 & 82 & 7.0 \\
\hline $\mathrm{C}_{32}$ & 95 & 16 & 103 & 5.0 & 81 & 5.0 & 88 & 6.0 \\
\hline $\mathrm{C}_{33}$ & 98 & 20 & 94 & 14 & 90 & 22 & 83 & 7.0 \\
\hline $\mathrm{C}_{34}$ & 97 & 21 & 105 & 2.0 & 80 & 0.0 & 83 & 7.0 \\
\hline $\mathrm{C}_{35}$ & 98 & 17 & 109 & 2.0 & 75 & 4.0 & 83 & 6.0 \\
\hline $\mathrm{C}_{36}$ & 92 & 18 & 107 & 3.0 & 71 & 5.0 & 94 & 6.0 \\
\hline $\mathrm{C}_{37}$ & 98 & 18 & 107 & 2.0 & 79 & 7.0 & 84 & 6.0 \\
\hline $\mathrm{C}_{38}$ & 100 & 21 & 103 & 5.0 & 78 & 5.0 & 88 & 7.0 \\
\hline $\mathrm{C}_{39}$ & 97 & 18 & 102 & 8.0 & 74 & 8.0 & 87 & 7.0 \\
\hline $\mathrm{C}_{40}$ & 90 & 25 & 103 & 6.0 & 76 & 14 & 96 & 7.0 \\
\hline
\end{tabular}

${ }^{\mathrm{a}} \mathrm{Rec}$ : recovery; ${ }^{\mathrm{B}} \mathrm{RSD}$ : relative standard deviation. 
to approximate $1 \mathrm{~mL}$ prior to the quantification step. In another test, the $\mathrm{N}_{2}$ pressure used in the pre-concentration step and the process of flask rinse containing the extract, to ensure a quantitative transfer, were evaluated. With the use of a higher nitrogen pressure $\left(2 \mathrm{kgf} \mathrm{cm}^{-2}\right)$ without washing the flask containing the analytes, the recoveries of PAH varied in the range from 40 to $68 \%$, and of $\mathrm{AH}$ from 58 to $92 \%$. These results were lower than the ones achieved using a nitrogen pressure of $0.5 \mathrm{kgf} \mathrm{cm}^{-2}$. Under this condition, the recovery percentages were in the range of 84 to $101 \%$ for PAH and 79 to $95 \%$ for AH. These data indicate that the use of a higher $\mathrm{N}_{2}$ pressure promotes a faster evaporation of the solvent, which probably results in higher losses especially for the more volatile compounds. In addition, a better quantitative transfer is achieved when the flask containing the analytes is rinsed with hexane:DCM (1:1). Although the variables pressure and number of rinses were changed at the same time, it is possible to affirm that the pressure has an important role in the recovery of the compounds. For both HA and PAH, there is a significant difference in the recovery of the more volatile compounds, meanwhile to the less volatile this difference exists, but is not so prominent. Considering these aspects, it was found that better results were achieved using rota-evaporator and subsequent volume reduction with $\mathrm{N}_{2}$ at a pressure of $0.5 \mathrm{kgf} \mathrm{cm}^{-2}$.

\section{Extraction step}

As it was observed losses of analytes by volatilization in the concentration step, an ice bath was used in the system of condensation to control the water temperature of reflux to minimize the losses during the extraction step. The percentage of recovery for $\mathrm{AH}$ and $\mathrm{PAH}$ compounds varied from 60 to $88 \%$ and from 50 to $95 \%$, respectively. The low recovery in the extraction stage was due to loss of compounds by volatilization during the process and also because of the losses involved in the concentration step.

During the extraction step, it was evaluated the efficiency of the extraction for 4,6 , and $8 \mathrm{~h}$. The solvents of extraction, acetone:DCM, hexane:DCM and DCM, were also evaluated. The best condition was achieved using $4 \mathrm{~h}$ of extraction with DCM and the recovery for PAH and AH ranged from 58 to $94 \%$ and from 69 to $99 \%$, respectively.

\section{Cleanup step}

$\mathrm{PAH}$ and $\mathrm{AH}$ are two classes of compounds with different polarities and the correct choice of the elution solvent has a crucial role in order to achieve a good recovery of these compounds. Firstly, the determination of total petroleum hydrocarbon (mixing $F_{1}$ and $F_{2}$ ) was evaluated. Subsequently, tests to find a condition that would allow the adequate separation of aliphatic and aromatic fractions were performed. Considering these aspects, different volumes of solvents to elute these compounds during the cleanup were evaluated. Recoveries for the aliphatic and PAH related to these tests are presented in Table 4.

Taking the results of test $1_{\mathrm{A}}$ to $1_{\mathrm{F}}$ into account, the better recovery values for both $\mathrm{AH}$ and $\mathrm{PAH}$ were obtained using the test $1_{\mathrm{E}}$. The test $1_{\mathrm{F}}$ is the same of $1_{\mathrm{E}}$, and it was performed to confirm the results. In the case of the fractionation of $\mathrm{AH}$ and $\mathrm{PAH}$ in different fractions, the test $2_{\mathrm{B}}$ provided the best results.

Table 4. Working condition for the cleanup and recovery of AH and PAH

\begin{tabular}{|c|c|c|c|c|}
\hline & \multirow{2}{*}{ Cleanup } & \multirow{2}{*}{ Solvents of elution } & \multicolumn{2}{|c|}{ Recovery / \% } \\
\hline & & & $\mathrm{AH}$ & PAH \\
\hline \multirow{6}{*}{$\begin{array}{l}\text { Total petroleum } \\
\text { hydrocarbon } \\
\text { determination }\end{array}$} & $1_{\mathrm{A}}$ & $\begin{array}{l}F_{1}=50 \mathrm{~mL} \text { of hexane } \\
F_{2}=50 \mathrm{~mL}(30 \text { hexane }+20 \mathrm{DCM})\end{array}$ & $51-114$ & $35-61$ \\
\hline & $1_{\mathrm{B}}$ & $\begin{array}{l}\mathrm{F}_{1}=25 \mathrm{~mL} \text { of hexane } \\
\mathrm{F}_{2}=50 \mathrm{~mL}(30 \text { hexane }+20 \mathrm{DCM})\end{array}$ & $60-134$ & $23-65$ \\
\hline & $1_{\mathrm{C}}$ & $\begin{array}{l}F_{1}=25 \mathrm{~mL} \text { of hexane } \\
F_{2}=50 \mathrm{~mL}(25 \text { hexane }+25 \mathrm{DCM})\end{array}$ & $86-113$ & $47-90$ \\
\hline & $1_{\mathrm{D}}$ & $\begin{array}{l}\mathrm{F}_{1}=25 \mathrm{~mL} \text { of hexane } \\
\mathrm{F}_{2}=30 \mathrm{~mL}(15 \text { hexane }+15 \mathrm{DCM})\end{array}$ & $77-120$ & $39-86$ \\
\hline & $1_{\mathrm{E}}$ & $\begin{array}{l}\mathrm{F}_{1}=25 \mathrm{~mL} \text { of hexane } \\
\mathrm{F}_{2}=50 \mathrm{~mL}(20 \text { hexane }+30 \mathrm{DCM})\end{array}$ & $64-99$ & $67-108$ \\
\hline & $1_{\mathrm{F}}$ & $\begin{array}{l}\mathrm{F}_{1}=25 \mathrm{~mL} \text { of hexane } \\
\mathrm{F}_{2}=50 \mathrm{~mL}(20 \text { hexane }+30 \mathrm{DCM})\end{array}$ & $66-98$ & $63-94$ \\
\hline \multirow{2}{*}{$\begin{array}{l}\text { Aliphatic } \\
\text { and aromatic } \\
\text { fractionation }\end{array}$} & $22_{\mathrm{A}}$ & $\begin{array}{l}\mathrm{F}_{1}=50 \mathrm{~mL} \text { of hexane } \\
\mathrm{F}_{2}=50 \mathrm{~mL}(20 \text { hexane }+30 \mathrm{DCM})\end{array}$ & $51-94$ & $40-95$ \\
\hline & $22_{\mathrm{B}}$ & $\begin{array}{l}\mathrm{F}_{1}=40 \mathrm{~mL} \text { of hexane } \\
\mathrm{F}_{2}=50 \mathrm{~mL}(20 \text { hexane }+30 \mathrm{DCM})\end{array}$ & 76-119 & 71-107 \\
\hline
\end{tabular}


Table 5. Best working conditions established for concentration, extraction and cleanup step

\begin{tabular}{ll}
\hline Step & Condition \\
\hline Extraction & rota-evaporator + ice bath \\
Concentration & $\begin{array}{l}\text { rota-evaporator }+ \text { ice bath } \\
\left(\mathrm{N}_{2} \text { pressure: } 0.5 \mathrm{kgf} \mathrm{cm}-2\right.\end{array}$ \\
& $\begin{array}{l}\mathrm{F}_{1}=25 \mathrm{~mL} \text { of hexane } / \mathrm{F}_{2}=50 \mathrm{~mL} \\
\text { (hexane:DCM } 2: 3)\end{array}$ \\
Cleanup (TPH) & $\begin{array}{l}\mathrm{F}_{1}=40 \mathrm{~mL} \text { of hexane } / \mathrm{F}_{2}=50 \mathrm{~mL} \\
\text { (hexane:DCM } 2: 3)\end{array}$ \\
Cleanup (aliphatic and &
\end{tabular}

The results show that the optimization process of the all steps have improved the overall recovery of the compounds, besides showing the existence of a large number of variables that can affect the results. In Table 5, the best working conditions for the development of each step are described.

\section{Validation}

\section{Parameters of merit}

The validation procedure is essential for the implementation and consolidation of developed methods. ${ }^{25}$ Thus, in order to validate the optimized method the following parameters of merit: linearity, limits of detection (LOD) and quantification (LOQ), precision and accuracy were evaluated. From the regression analysis of the analytical curves plotted, the linearity was studied in the concentration ranges: 9.6 to $1000 \mathrm{ng} \mathrm{mL}^{-1}$ for $16 \mathrm{PAH}$ and 0.5 to $50 \mu \mathrm{g} \mathrm{mL} \mathrm{m}^{-1}$ for aliphatic. Regression coefficients (R) varied from 0.995 to 0.999 for PAH and 0.996 to 0.999 for aliphatic and were considerated satisfactory according to the recommended by Metrology, Standardization and Industrial Quality (Inmetro, Brazil) $(\mathrm{R}>0.90) .{ }^{25}$

LOD for PAH was calculated based on signal-tonoise method, where the peak-to-peak noise around the analyte retention time is measured, and subsequently, the concentration of the analyte that would yield a signal equal to certain value of noise to signal ratio is estimated. ${ }^{24}$ In this study, the noise magnitude was measured by autointegrator of the chromatograph and LOD was determinate by equation 1 ,

$$
\mathrm{LOD}=\frac{3 \mathrm{C}}{\mathrm{S} / \mathrm{N}}
$$

where $\mathrm{C}\left(\mathrm{ng} \mathrm{mL} \mathrm{m}^{-1}\right)$ is the lowest concentration of calibration curve and $\mathrm{S} / \mathrm{N}$ is the signal-to-noise ratio. On the other hand, the LOD for AH was calculated based on the parameters of the analytical curve according equation 2 below, where $\mathrm{s}$ is the estimated standard deviation of the equation of calibration curve and $S$ is the slope of the curve.
$\mathrm{LOD}=3.3 \frac{\mathrm{s}}{\mathrm{S}}$

LOD values ranged from 0.02 to $0.06 \mathrm{ng} \mathrm{mL}^{-1}$ for PAH and 0.03 to $0.16 \mu \mathrm{g} \mathrm{mL}^{-1}$ for aliphatic. LOQ values were considered as the lowest concentration levels of analytical curve $\left(9.6 \mathrm{ng} \mathrm{mL}^{-1}\right.$ for $16 \mathrm{PAH}$ and $0.5 \mu \mathrm{g} \mathrm{mL}-1$ for aliphatic). ${ }^{25}$ Therefore, the values of LOD and LOQ demonstrated the high sensitivity of the method.

The accuracy of the whole procedure was verified based on the fortification of known concentrations of $\mathrm{AH}$ and $\mathrm{PAH}$ in sodium sulfate, and the precision was expressed as relative standard deviations (RSD) calculated from the recovery. The results obtained are showed in Figure 1. The RSD values ranged from 8 to $18 \%$ and 4 to $23 \%$, for PAH and HA respectively. These values were considered satisfactory, since in trace analysis, values up to $20 \%$ are acceptable. ${ }^{25}$ The compounds $\mathrm{C}_{25}, \mathrm{C}_{26}$ and $\mathrm{C}_{27}$ presented $\mathrm{RSD}$ values higher than $20 \%$, due co-elution
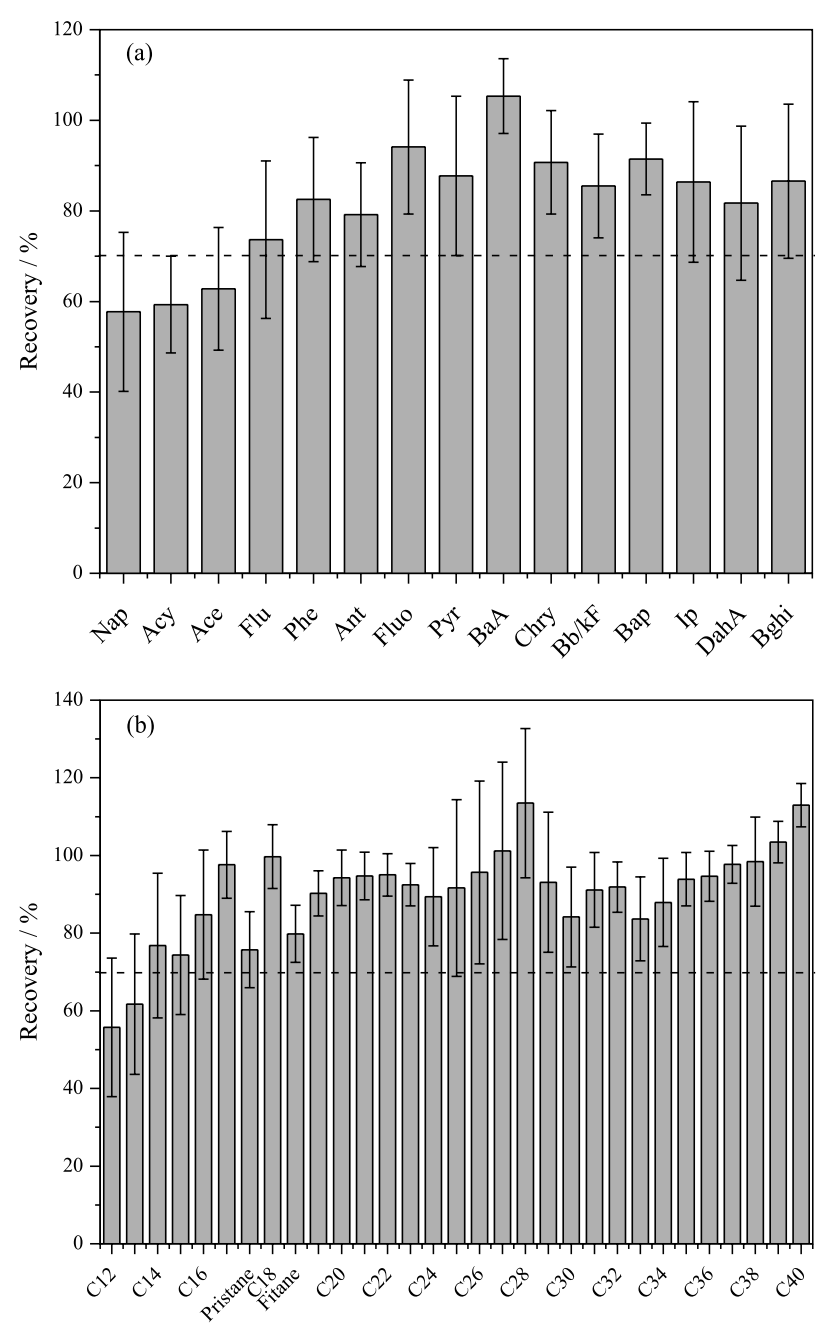

Figure 1. (a) PAH and (b) aliphatic recoveries from fortified sodium sulfate with $150 \mathrm{ng} \mathrm{g}^{-1}$ and $10 \mu \mathrm{g} \mathrm{g}^{-1}$, respectively. Vertical bars represent the standard deviation $(n=6)$. 
problems that hindered the integration of the areas of these compounds.

The recovery percentage obtained for $\mathrm{AH}$ and $\mathrm{PAH}$ were 59 to $105 \%$ and 55 to $113 \%$, respectively, these values are considered satisfactory for the majority of compounds. PAH, such as naphthalene, acenaphthylene and acenaphthene, showed recoveries lower than $70 \%$, which could be explained due to their more significant losses by volatility during the multi-step process of concentration, extraction and cleanup. This was evidenced by recovery tests presented for these steps (Figure 1a). Regarding $\mathrm{AH}$ that showed no satisfactory recoveries $\left(\mathrm{C}_{12}\right.$ and $\left.\mathrm{C}_{13}\right)$, it was probably for the same reasons to $\mathrm{PAH}$.

The recovery values obtained for the surrogates were superior to $70 \%$ for the both classes of compounds. Based on the results obtained, the spiking and recovery tests can be considered quite satisfactory. Moreover, these results showed that the extraction time of $4 \mathrm{~h}$ was sufficient to recover the analytes from the sample of sulfate.
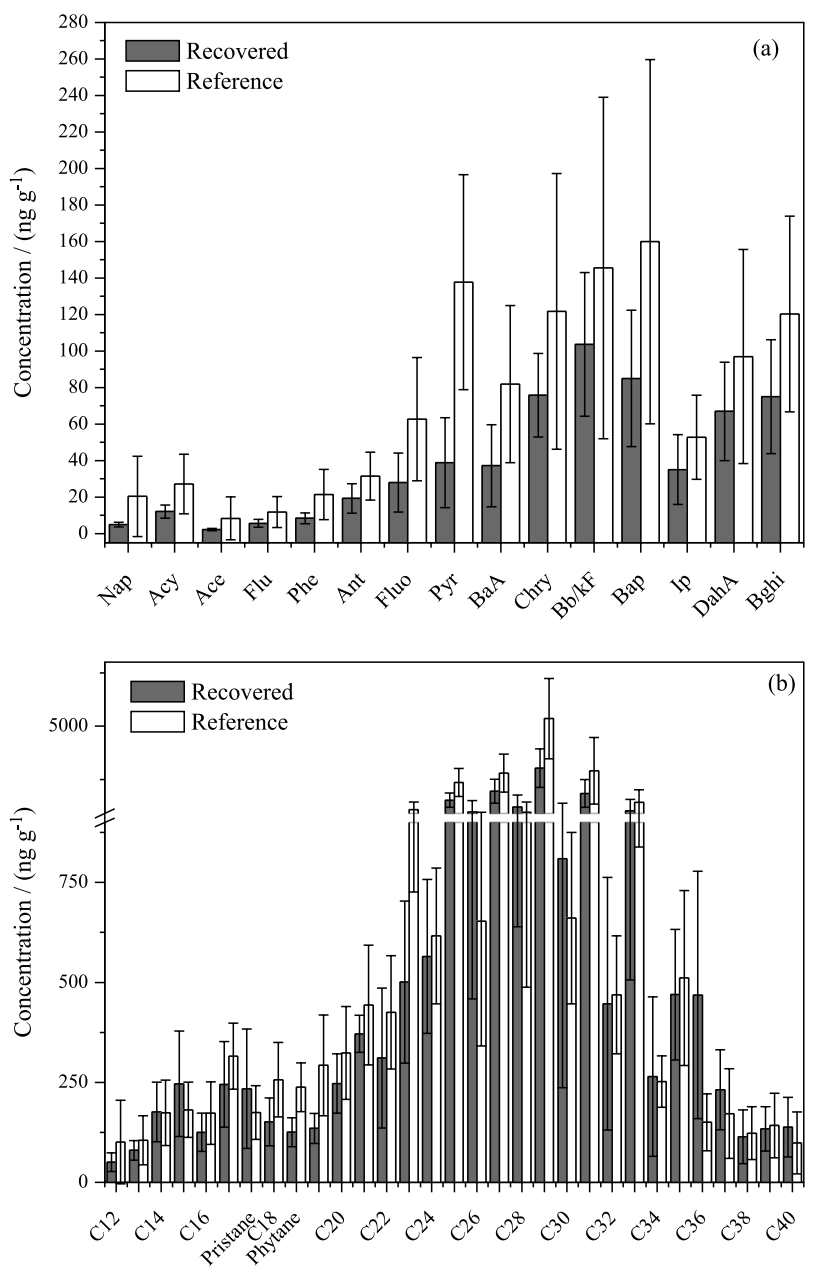

Figure 2. (a) PAH and (b) aliphatic concentrations recovered from reference sediment. Vertical bars represent the standard deviation ( $\mathrm{n}=$ $10)$ for the recovered and for the reference material $(n=13)$.
Aliphatic and aromatic hydrocarbon extractions from a reference material and certified reference material

The recovery values obtained for the extraction of $\mathrm{AH}$ and PAH from reference sediment are shown in Figure 2. According to Figure 2a, the values of absolute standard deviations for PAH were 1.2 to 39 , and for the reference material 8.4 and 97. For all PAH, the deviation values obtained were lower than the values of the reference sediment. The recovery ranged from 37 to $123 \%$, and the average recovery of the surrogate added was $80 \%$, also had values considered acceptable by the literature. ${ }^{24,25}$

For $\mathrm{AH}$, the absolute standard deviations, shown in Figure 2b, were lower than those presented by the reference material. Moreover, the recovery range for most compounds was between 70 and $120 \%$, and the average recovery for the surrogate was $95 \%$. There is also a better recovery of the molecular weight intermediate compounds $\left(\mathrm{C}_{22}\right.$ to $\left.\mathrm{C}_{33}\right)$, which are less influenced by volatilization losses, and were in higher concentration in reference material. The results obtained for the material reference were comparable to results which have been published using Soxhlet extraction for determining HA and PAH in river sediment. ${ }^{26,27}$

In addition, it was used a certified reference material to validate the method. The test was performed only for PAH, because there is no certified reference material for $\mathrm{AH}$. The recovery values obtained for PAH are shown in Figure 3.

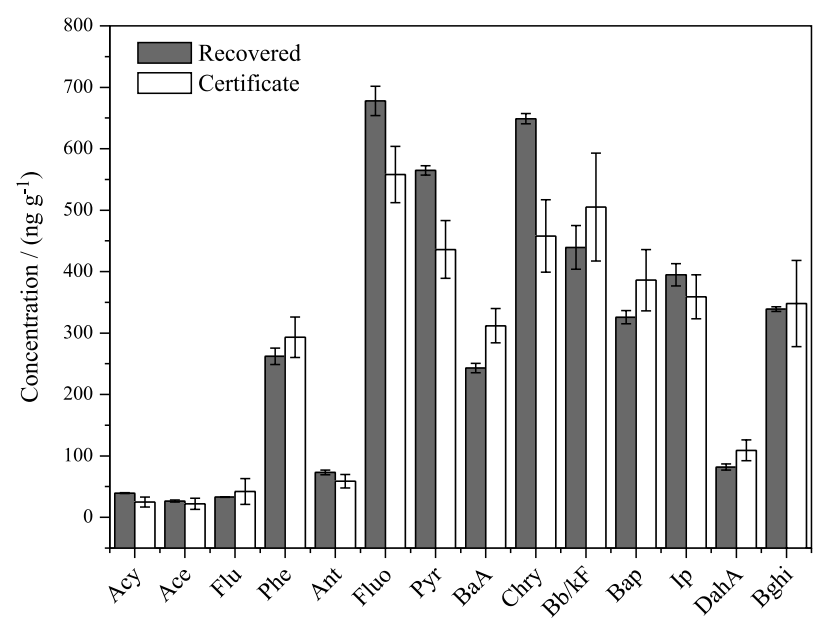

Figure 3. PAH concentrations recovered from certified reference sediment. Vertical bars represent the standard deviation $(n=3)$ for the recovered and for the certificate $(n=3)$.

The recovery range for $\mathrm{PAH}$ was within the range of 70-120\%, with values of absolute standard deviation lower than those presented by the certified reference material. These results demonstrate the good efficiency of the method. 


\section{Conclusions}

This study was developed with the aim to improve an already established method. In general, the working conditions employed in the extraction of aliphatic and aromatic hydrocarbons by Soxhlet system enabled the adjustment and improvement this method, already consolidated. The changes made for the concentration and extraction step decreased considerably the losses by volatilization of compounds, especially for PAH with higher vapor pressure. In the cleanup step, the tests gave satisfactory results both for the determination of TPH and for fractionation of the compounds, showing the importance of correct choice of elution solvent on the efficiency of this step. The results obtained with the validation demonstrate that it is possible to obtain results with high levels of analytical reliability.

Usually, the discrepancies among results and work conditions from the application of established methods cited in the literature are not questioned or justified. Therefore, the present work raised a number of difficulties related to the implementation of a method reflecting the working conditions of many laboratories.

\section{Acknowledgments}

The authors are thankful to CAPES, CNPq and Petrobras for financial support.

\section{References}

1. Guo, W.; Mengchang, H.; Yang, Z.; Lin, C.; Quan, X.; Men, B.; J. Hazard. Mater. 2009, 164, 1379.

2. Martins, C. C.; Bícego M. C.; Taniguchi S.; Montone, R. C.; Antarct. Sci. 2004, 16, 117.

3. Tolosa, I.; Mora, S.; Sheikholeslami, M. R.; Villeneuve, J.; Bartocci, J.; Cattini, C.; Mar. Pollut. Bull. 2004, 48, 44.

4. Ventura, G. T.; Kenig, F.; Reddy, C. M.; Frysinger, G. S.; Nelson, R. K.; Mooy, B.; Gaines, R. B.; Org. Geochem. 2008, 39, 846.

5. Orecchio, S.; J. Hazard. Mater. 2010, 176, 339.

6. Bossio, J. P.; Harry, J.; Kinney, C. A.; Chemosphere 2008, 70, 858.

7. Pietzsch, R.; Patchineelam, R. S.; Torres, M. P. J.; Mar. Chem. 2010, $118,56$.
8. Berset, J. D.; Ejem, M.; Holzer, R.; Lischer, P.; Anal. Chim. Acta 1999, 383, 263.

9. Leite, N. F.; Zamora, P. G. P.; Grassi, M. T.; J. Chromatogr., A 2008, 1192, 273.

10. Brum, M. D.; Netto, P. D. A.; J. Hazard. Mater. 2009, $165,447$.

11. Heemken, O. P.; Theobald, N.; Wenclawiak, B. W.; Anal. Chem. 1997, 69, 2171.

12. Mostafa, R. A.; Wade, L. T.; Sweet, T. S.; Al-Alimi, A. K. A.; J. Mar. Syst. 2009, 78, 1.

13. Librando, V.; Hutzinger, O.; Tringali, G.; Aresta, M.; Chemosphere 2004, 54, 1189.

14. Gan, S.; Lau, V. E.; Ng, K. H.; J. Hazard. Mater. 2009, 172, 532.

15. Budzinski, H.; Letellier, M.; Garrigues, P.; Le Menach, K.; J. Chromatogr. A. 1999, 837, 187

16. Pino, V.; Ayala, J. H.; Afonso, A. M.; González, V.; Anal. Chim. Acta 2003, 477, 81.

17. Serrano, A.; Gallego M.; J. Chromatogr., A 2006, 1104, 323.

18. Jardim, W. F.; Sodré, F. F.; Quim. Nova 2009, 32, 1083.

19. Sun, P.; Weavers, K. L.; Taerakul, P.; Walker, H. W.; Chemosphere 2005, 62, 265.

20. Crespo, M. O. P.; Yuist, M. A. L.; Ecotoxicol. Environ. Saf. 2006, 64, 400.

21. Richter, P.; Jiménez, M.; Salazar, R.; Maricán, A.; J. Chromatogr., A 2006, 1132, 15.

22. http://www.epa.gov/ accessed in May 2011.

23. Luz, L. P.; Filho, P. J. S.; Sousa, E. E. H.; Kerstner, T.; Caramão, E. B.; Microchem. J. 2010, 96, 161.

24. Ribani, M.; Bottoli, C. B. G.; Collins, C. H.; Jardim, I. C. F.; Melo, L. F. C.; Quim. Nova 2004, 27, 771.

25. Instituto Nacional de Metrologia, Normalização e Qualidade Industrial (INMETRO); Orientações sobre Validação de Métodos de Ensaios Químicos, DOQ-CGCRE-008, 2003. http://www.inmetro.gov.br/ accessed in May 2011.

26. Song,Y.F.; Jing, X.; Fleischmann, S.; Wilke, B. M.; Shouming, O.; Zheng, J.; Richardson, B. J.; Lam, P. K. S.; Chemosphere 2002, 48, 993.

27. Itoh, N.; Numata, M.; Aoyagi, Y.; Anal. Chim. Acta 2008, 612, 44.

Submitted: November 22, 2011

Published online: July 12, 2012 